\title{
Pengaruh Lingkungan Kerja Dan Motivasi Kerja Terhadap Kinerja Karyawan
}

\author{
T.Pratami, R.Purnama, B.Widjajanta \\ Universitas Pendidikan Indonesia \\ tyas.oki@student.upi.edu
}

\begin{abstract}
The background of this research is a low performance of the employee. It is a decline in performance appraisal results and reduced production which exceeds the tolerance limit of the company . The purpose of reasearch (1) find out the description of work environment, (2) find out the description of motivation, (3) find out the description of employee's performance, (4) find out the effect of work environment on employee's performance, (5) find out the effect of motivation on employee's performance, (6) find out the influence of work environment and motivation on employee's performance in PT. Harian Pos Kota di Jakarta. and 7) The relationship between work environment with motivation. The research is an employee's of PT. Harian Pos Kota di Jakarta. This type of research is descriptive and verification. The method in this research is random sampling with sample 175 peoples. Technical analysis of the data used in multiple linear regression with SPSS 24.0. The result of this research is employee's performance is positively influenced by work environment, employee's performance is positively influenced by the motivation, employee's performance is positively influenced by the work. environmental and motivation, and there is a positive relationship by correlation between work environment and motivation.
\end{abstract}

\footnotetext{
ABSTRAK

Latar belakang penelitian ini adalah rendahnya kinerja karyawan, ditandai dengan hasil penilaian kinerja yang menurun dan menurunnya hasil produksi melebihi batas toleransi perusahaan. Penelitian ini bertujuan untuk (1) mengetahui gambaran lingkungan kerja, (2) mengetahui gambaran motivasi kerja, (3) mengetahui gambaran kinerja karyawan, (4) mengetahui pengaruh lingkungan kerja terhadap kinerja karyawan, (5) mengetahui pengaruh motivasi kerja terhadap kinerja karyawan, (6) mengetahui pengaruh lingkungan kerja dan motivasi kerja terhadap kinerja PT. Harian Pos Kota Jakarta dan (7) hubungan antara lingkungan kerja dengan motivasi kerja PT. Harian Pos Kota Jakarta. Objek yang menjadi unit analisis dalam penelitian ini adalah karyawan PT. Harian Pos Kota Jakarta. Jenis penelitian ini adalah deskriptif dan verifikasi. Metode yang digunakan adalah explanatory survey dengan teknik sampel
}

\section{ARTICLE INFO: Article history: \\ Received 5 Februari 2018 \\ Revised 6 Februari 2018 \\ Accepted 7 Februari 2016 \\ Available online 24 Mei 2018}

\section{Keywords:}

Employee's Performance

Transformational Leadership,

Work Environment,

\author{
Kata Kunci: \\ Kinerja Karyawan \\ Lingkungan Kerja, \\ Motivasi Kerja,
}


yaitu teknik proportionate stratifies random sampling dengan jumlah sampel 175 responden. Teknik analisa data yang digunakan adalah regresi liniear berganda dengan alat bantu software komputer SPSS 24.0. Hasil temuan dalam penelitian ini menunjukkan bahwa gambaran lingkungan kerja dalam kategori baik, gambaran motivasi kerja dalam kategori baik, gambaran kinerja karyawan dalam kategori baik, kinerja karyawan dipengaruhi secara positif oleh lingkungan kerja, kinerja karyawan dipengaruhi secara positif oleh motivasi kerja dan terdapat hubungan atau korelasi aktif antara lingkungan kerja dengan motivasi kerja.

\section{PENDAHULUAN}

Kinerja merupakan sebuah proses yang dilakukan oleh sekelompok orang dalam suatu perusahaan untuk menciptakan suatu produk atau jasa, selain itu kinerja juga identik dengan proses pekerjaan dikalangan karyawan. Tercapai tidaknya tujuan suatu perusahaan sangat ditentukan oleh kinerja karyawan karena karyawan merupakan pemeran utama yang melaksanakan pencapain tugas-tugas perusahaan dan akan memberikan hasil bagi perusahaan

Terdapat beberapa faktor yang dapat mempengaruhi kinerja pegawai, seperti yang dikemukakan oleh Chew (2013) salah satunya yaitu lingkungan kerja. Penjelasan dari faktor lingkungan yaitu kerberhasilan suatu perusahaan terutama bagi karyawan adalah bagaimana lingkungan yang menjadi tempat bekerjanya para karyawan.

Menurut Berg dan Baron dalam Gouzaly Saydam (2010) lingkungan kerja adalah keseluruhan sarana dan prasarana kerja yang ada disekitar pegawai yang sedang melakukan pekerjaan yang dapat mempengaruhi pelaksanaan pekerjaan itu sendiri. Mike (2010: 141) mengungkapakan bahwa, tempat kerja yang efektif adalah sebuah lingkungan di mana hasil yang dapat dicapai seperti yang diharapkan oleh manajemen.

Selain itu, menurut Hashim Zameer et al. (2014) menyimpulkan bahwa motivasi kerja berpengaruh positif dan signifikan terhadap kinerja karyawan. Menurut Suwardi dan Utomo (2011), Hamid (2012), Murti dan Veronika (2013), serta Permanasari (2013) ditemukan bahwa motivasi kerja secara signifikan memiliki pengaruh positif terhadap kinerja karyawan.

Menurut Gomez-Mejia, Balkin dan Cardy (2012) yang mengidentifikasi dimensi kinerja terdiri dari : (1) Quality of Work, yaitu kualitas kerja yang dicapai berdasatkan syarat-syarat kesesuaian dan kesiapannya (2) Quantity of Work Performed,yaitu jumlah kerja yang dilakukan dalam suatu periode waktu yang ditentukan (3) Interpersonal effectiveness, yaitu menyangkut kepribadian, kepemimpinan, dan integritas pribadi (4) Competencies, yaitu luasnya pengetahuan mengenai pekerjaan dan keterampilannya (5) Job Knowladge, yaitu luasnya pengetahuan mengenai pekerjaan dan keterampilannya.

Rendahnya kinerja akan berpengaruh terhadap perusahaan, hal ini mengakibatkan pencapaian tujuan perusahaan tidak maksimal. Fenomena pada masalah penurunan kinerja tersebut dialami oleh karyawan pada beberapa perusahaan manufaktur di Indonesa salah satunya pada CV. Bi-ensi Fesyenindo di Bandung.

Hal tersebut dapat dilihat pada data hasil penilaian kinerja di PT. Harian Pos Kota Jakarta pada tahun 2011 hingga 2016 perusahaan relatif mengalami 
penurunan pada beberapa kategori terutama pada karyawan berkinerja kurang. Pada dasarnya perusahaan telah menetapkan target untuk karyawannya berada pada Grade 1, 2 dan Grade 3, tetapi pada kenyataannya masih ada karyawan yang berada pada Grade 4 atau kurang dengan persentase yang fluktuatif. Masalah yang dialami PT. Harian Pos Kota adalah penurunan kinerja karyawan yang disebabkan oleh rendahnya lingkungan kerja dan kurang maksimalnya motivasi kerja untuk menunjang keberhasilan suatu perusahaan di PT. Harian Pos Kota sehingga membuat hasil kinerja menurun dan tidak sesuai dengan target yang ditetapkan oleh perusahaan. Oleh karena itu peneliti mengambil judul Pengaruh Lingkungan Kerja dan Motivasi Kerja Terhadap Kinerja Karyawan.

\section{METODE PENELITIAN}

Unit analisis yang dijadikan responden dalam penelitian ini adalah karyawan PT. Harian Pos Kota Jakarta. Oleh karena itu akan diteliti pengaruh lingkungan kerja dan motivasi kerja terhadap kinerja PT. Harian Pos Kota Jakarta. Penelitian ini dilakukan dalam kurun waktu kurang dari setengah tahun, maka metode yang digunakan adalah cross sectional method, pengumpulan informasi dari subjek penelitian hanya dilakukan satu kali dalam satu periode waktu, sehingga penelitian ini merupakan cross sectional. Penelitian ini dilakukan pada bulan April hingga Agustus 2017. Populasi dalam penelitian ini adalah karyawan PT. Harian Pos Kota pada tahun 2017 sebanyak N: 175 anggota.

\section{HASIL DAN PEMBAHASAN}

Hasil pengujian antar variable kemampuan $\mathrm{X}_{1}$ dan $\mathrm{X}_{2}$ terhadap $\mathrm{Y}$ secara keseluruhan memberikan hasil yang signifikan. Maka untuk mengetahui antara variabel $\mathrm{X}_{1}$ lingkungan kerja dan variabel $\mathrm{X}_{2}$ motivasi kerja terhadap variabel kinerja karyawan (Y) dapat dilanjutkan dengan pengujian secara parsial.

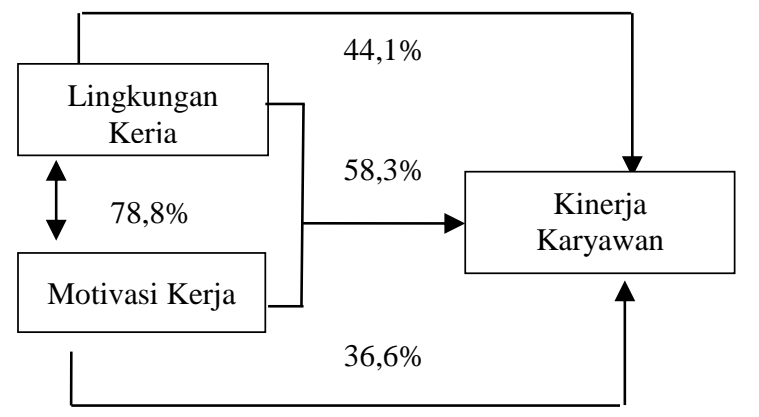

Gambar. 1

Pengaruh Lingkungan Kerja Dan Motivasi Kerja Terhadap Kinerja Karyawan

Berdasarkan Gambar 1 menunjukan koefisien jalur antara lingkungan kerja dan motivasi kerja dimana besar koefisien kemampuan memberikan pengaruh signifikan terhadap kinerja karyawan.

Berdasarkan hasil penelitian yang dilakukan oleh Dobre (2013) ada beberapa faktor yang mempengaruhi kinerja karyawan antara lain, motivation, appraisals,ability, job satisfaction, training and development. Menurut penelitian terdahulunya Victoria Büsch, Dennis Dittrich, Uta Lieberum (2010) menunjukan bahwa, terdapat dampak positif yang signifikan pada lingkungan terhadap kinerja karyawan.

Selain lingkungan terdapat faktor lain yang mempengaruhi kinerja yaitu motivasi kerja. Didukung dengan penelitian terdahulu yang dilakukan oleh Shehzad and Zameer (2014) menjelaskan bahwa tanpa memotivasi karyawan suatu perusahaan tidak akan dapat mencapai tujuannya karena motivasi karyawan dan lingkungan mereka secara kolektif berpartisipasi dalam kinerja karyawan dan tugas yang sulit yang diberikan oleh 
manajer adalah memperoleh hasil yang maksimal, baik motivasi yang berasal dari dalam diri karyawan itu sendiri ataupun motivasi yang berasal dari luar, karena motivasi menjadi pendorong seseorang melaksanakan suatu kegiatan guna mendapat hasil yang terbaik (Manmohan Joshi, 2013:55). Oleh karena itu tidak heran jika karyawan yang mempunyai motivasi kerja yang tinggi biasanya memiliki kinerja yang tinggi. Untuk itu motivasi kerja karyawan perlu dibangkitkan agar karyawan dapat menghasilkan kinerja yang terbaik, semakin tinggi motivasi karyawan dalam bekerja maka kinerja yang dihasilkan pun tinggi.

Hal ini menunjukkan bahwa jika semakin baik perusahaan memperbaiki lingkungannya dan motivasi kerja kepada karyawan maka akan semakin baik juga kinerja karyawan yang dihasilkan pada PT. Harian Pos Kota.

\section{KESIMPULAN}

Variabel lingkungan kerja dan motivasi kerja memiliki pengaruh yang positif dan signifikan terhadap kinerja karyawan dengan pengaruh yang cukup tinggi dari kedua variabel tersebut untuk mempengaruhi kinerja karyawan dalam menghasilkan output yang maksimal. Hal ini menunjukkan bahwa jika semakin baik perusahaan memperbaiki lingkungannya dan motivasi kerja kepada karyawan maka akan semakin baik juga kinerja karyawan yang dihasilkan pada PT. Harian Pos Kota.

\section{DAFTAR PUSTAKA}

Dobre Ovidiu Iluita. 2013. "Employee Motivation and Organizational Performance". Vol. 5 Iss 1, pp. 53. Review of Applied Socio-Economic Research 2247-6172
Joshi, Manmohan. 2013. Human Resources Management Edition $1^{\text {th }}$. Venns Publishing Denmark

Mejia, Gomez., Luis R and David B. Balkin and Robert L. Cardy. 2012. Managing Human Resources.. New Jersey: Pearson Education

Victoria Büsch, et al. 2010. "Determinants of Work Motivation and Work Ability among Older Workers and Implications for the Desire for Continued Emplymnent". Comparative Population Studies - Zeitschrift für Bevölkerungswissenschaft. Vol. 35, No. 4

Zameer, Hasim., Shehzad Ali. 2014. "The Impact of the Motivation on the Employee's Performance in Beverage Industry of Pakistan". International Journal of Academic Research in Accounting, Finance and Management Sciences. Vol. 4, No. 1, pp. 293-298. CHRMARS [ISSN 2225-8329] 